Vol. 14 (2005): 181-188.

\title{
Extractability of slurry and fertilizer phosphorus in soil after repeated freezing
}

Helena Soinne and Tommi Peltovuori

Department of Applied Chemistry and Microbiology, FI-00014 University of Helsinki, Finland, e-mail: helena.soinne@helsinki.fi

\begin{abstract}
The potential effects of freezing on phosphorus (P) chemistry in Finnish soils are not well known. We studied the effects of multiple freeze-thaw cycles on soil $\mathrm{P}$ chemistry in a laboratory incubation experiment with one organic and one mineral surface soil. The soils were incubated at $+5^{\circ} \mathrm{C}$ or at alternating $+5 /-20^{\circ} \mathrm{C}$ temperatures for 24 weeks, either without amendment or amended with pig slurry or with commercial compound fertilizer (NPK 20-3-9). After incubation, the soils were analyzed for water-soluble reactive and unreactive $\mathrm{P}$, and acid ammonium acetate soluble $\mathrm{P}\left(\mathrm{P}_{\mathrm{AAA}}\right)$. Freezing and thawing of soils during the incubation had no significant effect on any of the water-soluble $\mathrm{P}$ fractions or $\mathrm{P}_{\mathrm{AAA}}$. The outcome was most likely a consequence of the good $\mathrm{P}$ status of the soils, which masked the gentle effects of freezing. According to these results, the time of soil sampling (fall vs. spring) has no effect on P test results on soils with a good P status. Concentrations of soluble $\mathrm{P}$ after incubation were roughly twice as high in the slurry treatments than in the fertilizer treatments, demonstrating potentially better long-term availability of slurry P.
\end{abstract}

Key words: fertilizers, freezing, incubation, phosphorus, pig slurry, soil analysis

\section{Introduction}

Phosphorus $(\mathrm{P})$ is a critical nutrient in agricultural soils, both in terms of crop growth and environmental effects of production. The bioavailability of $\mathrm{P}$ in soil should be maintained high enough to sustain yields but too high levels should be avoided in order to reduce the risk of P losses to surface waters. A multitude of factors affect soil $\mathrm{P}$ status and $\mathrm{P}$ fertilization. Freezing of soil is possibly one of the factors influencing soil P chemistry at Nordic conditions, yet not well examined. Freezing of soil is known to affect soil conditions through various physical, physico-chemical, and biological mechanisms (Edwards and Cresser 1992). The effects of freezing on the physical properties of soil (Miller 1980) have been studied more extensively than the mechanisms affecting soil chemistry. In Finland, where most soils freeze annually, the effects of freezing on soil physics have also created interest (Sillanpää 1961, Kivisaari 1979), but hard- 
ly any studies have dealt with its effects on soil chemistry.

Seasonal changes in soil $\mathrm{P}$ test values have been demonstrated in a number of - predominantly Canadian - studies. Both Campbell et al. (1984) and Nyborg et al. (1992) found that routine agronomic soil $\mathrm{P}$ test resulted in higher $\mathrm{P}$ concentrations in samples taken in the winter or in the spring than in the previous fall. Freezing appears to affect the solubility of $\mathrm{P}$ primarily through its effects on organic and biological soil constituents. In laboratory experiments, freezing has enhanced the solubility of $\mathrm{P}$, especially in soils of high organic matter content (Allen and Grimshaw 1962) and increased the concentration of organic $\mathrm{P}$ in the soil solution (Ron Vaz et al. 1994). In mineral soils of high natural $\mathrm{P}$ status, freezing may increase the availability of $\mathrm{P}$ by breaking down soil aggregates, thus increasing the desorptive surface area and enhancing dissolution of P minerals (Hinman 1970). Multiple freeze-thaw incidents have usually intensified the effects of a single freezing cycle (Hinman 1970, Ron Vaz et al. 1994).

In some regards, freezing has been compared to drying because it concentrates soil solutes to a small volume of liquid (Miller 1980). Theoretically, high ionic strength in soil solution enhances $\mathrm{P}$ sorption because the thickness of the diffuse double layer decreases (Ryden and Syers 1975). It can be hypothesized that two simultaneous and counteracting mechanisms affect $\mathrm{P}$ solubility in freezing soil: increased $\mathrm{P}$ solubilization from organic soil constituents and enhanced sorption on $\mathrm{P}$ sorptive surfaces.

In a preceding study (Peltovuori and Soinne 2005), we found only modest effects of freezing on the P sorptive surfaces in four mineral soils. The present study was carried out to investigate the possible effects of multiple freeze-thaw cycles on the behavior of organic and inorganic $\mathrm{P}$ amendments both in organic and mineral soils. We expected to see increased solubility of $\mathrm{P}$ in organic soil and in all soils after organic $\mathrm{P}$ amendment because freezing enhances the deterioration and solubility of organic material (Wang and Bettany 1993). We also hypothesized that freezing increases sorption of $\mathrm{P}$ on mineral soils. The practical rel- evance of this study lies in its efforts to explore the effects of freezing on fall-applied $\mathrm{P}$ for winter crops and to determine the most appropriate timing of sampling for P soil testing.

\section{Material and methods}

\section{Experimental soils}

The experimental soils (Table 1) were taken in the surface horizons of cultivated soils in southern Finland: the organic soil was taken from the Ap horizon of a Histic Cryaquept (Soil Survey Staff 1998) (N 6040.31', E 24³0.65', datum WGS84) and the mineral soil from the Ap horizon of a Typic Cryaquent ( $\mathrm{N} \mathrm{60} 40.43^{\prime}$, E 2430.61'). The sampling sites are located approximately $200 \mathrm{~m}$ apart on the same field and have practically identical cropping histories dominated by sugarbeet, oat, and barley. The soils were sampled in the fall and stored at sampling moisture at $+5^{\circ} \mathrm{C}$ for 6 months. Clay percentage was determined with a pipette method (Elonen 1971), oxalate-extractable metals $\left(\mathrm{Fe}_{\text {ox }}\right.$ and $\left.\mathrm{Al}_{\mathrm{ox}}\right)$ were extracted with acid ammonium oxalate $\left(0.05 \mathrm{M}\left(\mathrm{NH}_{4}\right)_{2} \mathrm{C}_{2} \mathrm{O}_{4} \cdot \mathrm{H}_{2} \mathrm{O}, \mathrm{pH} 3.3 ; 1: 20\right.$ $\mathrm{w}: \mathrm{v} ; 2 \mathrm{~h}$ shaking in the dark) according to Niskanen (1989), and soil organic carbon was determined with a Leco ${ }^{\circledR}$ CNS-1000 analyzer.

Table 1. Selected properties of the soils used in the incubation experiment.

\begin{tabular}{lcc}
\hline & Organic soil & Mineral soil \\
\hline Organic carbon, \% & 12.8 & 1.7 \\
Clay in the mineral fraction, \% & 24 & 25 \\
$\mathrm{pH}\left(0.01 \mathrm{M} \mathrm{CaCl}_{2}\right)$ & 6.4 & 7.3 \\
$\mathrm{Al}_{\mathrm{ox}}, \mathrm{mmol} \mathrm{kg}^{-1}$ & 63.6 & 39.8 \\
$\mathrm{Fe}_{\mathrm{ox}}, \mathrm{mmol} \mathrm{kg}^{-1}$ & 77.2 & 54.6 \\
\hline
\end{tabular}

$\mathrm{Al}_{\mathrm{ox}}, \mathrm{Fe}_{\mathrm{ox}}=$ oxalate-extractable $\mathrm{Al}$ and $\mathrm{Fe}$ 


\section{Incubation experiment}

The effect of freeze-thaw cycles on soil $\mathrm{P}$ in the organic and mineral soils amended with pig slurry or NPK fertilizer was investigated in a laboratory incubation experiment. The soils were sieved (5 $\mathrm{mm}$ ), homogenized and placed into experimental vessels without drying at any stage. The amount of soil in the vessels was $0.46 \mathrm{dm}^{3}$, which corresponded to $500 \mathrm{~g}$ of the mineral soil and $308 \mathrm{~g}$ of the organic soil on a dry matter basis.

Prior to incubation, one third of the vessels of each soil were amended with fine-ground commercial compound fertilizer (NPK 20-3-9), one-third with pig slurry, and one third was incubated with no additions (control). The $\mathrm{P}$ additions of the treatments are presented in Table 2 . The total $\mathrm{P}$ addition in fertilizer corresponds to $70 \mathrm{~kg} \mathrm{ha}^{-1}$ and the addition in the slurry to $94 \mathrm{~kg} \mathrm{ha}^{-1}$ (in $0.2 \mathrm{~m}$ plow layer). According to current fertilization guidelines in Finland, only $75 \%$ of slurry $\mathrm{P}\left(=71 \mathrm{~kg} \mathrm{ha}^{-1}\right)$ is accounted for as plant available (Viljavuuspalvelu 2000). At the onset of incubation, soil moisture was adjusted to approximately $\mathrm{pF} 1$ (gravimetric moisture $65 \%$ in the organic soil and $25 \%$ in the mineral soil) and maintained at this level throughout the experiment. During incubation the vessels were covered with perforated plastic. Half of the vessels were incubated at a constant temperature of $+5^{\circ} \mathrm{C}$ (monitored temperature range $4.0-6.5^{\circ} \mathrm{C}$ ) (referred to as +5 ), and the other half in alternating two-week periods at $+5^{\circ} \mathrm{C}$ and at $-20^{\circ} \mathrm{C}$ (monitored range $-17.4--22.3^{\circ} \mathrm{C}$ ) (referred to as -20 ) for 24 weeks. Repeated freezing simulated the freeze-thaw cycles occurring in the surface soil horizon during an average winter. After incubation, the soils in the vessels were mixed and sampled for analyses. All treatments were carried out with three replicates; the total number of vessels in the experiment was 36 .

\section{Phosphorus analyses}

Soil organic $\mathrm{P}\left(\mathrm{P}_{\text {org }}\right)$ was determined using the ignition method of Kuo (1996) as the difference between acid-soluble $\mathrm{P}$ in samples ignited for $1 \mathrm{~h}$ at $550^{\circ} \mathrm{C}$ and non-ignited samples. Extractions $(16 \mathrm{~h})$ were done with $2 \mathrm{~g}$ soil samples and $50 \mathrm{ml}$ of 0.5 $\mathrm{M} \mathrm{H}_{2} \mathrm{SO}_{4}$. Extractants were filtered through a 0.45 $\mu \mathrm{m}$ Nuclepore ${ }^{\circledR}$ polycarbonate filter prior to neutralization and analysis using an ascorbic acid method. Below, $\mathrm{H}_{2} \mathrm{SO}_{4}$-soluble $\mathrm{P}$ after ignition is referred to as total soil $\mathrm{P}$ (TP). Total content of $\mathrm{P}$ in the fertilizer and sludge was analyzed in microwave digested nitric acid extracts using the ascorbic acid method of Kuo (1996). For the sludge, the relative standard deviation of the analysis was $17 \%$; for the fertilizer it was $9 \%$. Acid ammonium acetate extractable $\mathrm{P}\left(\mathrm{P}_{\mathrm{AAA}}\right)$, a routine advisory $\mathrm{P}$ test in Finland, was determined as in Vuorinen and Mäkitie (1955) (0.5 M CH $\mathrm{COONH}_{4}, 0.5 \mathrm{M}$ $\mathrm{CH}_{3} \mathrm{COOH}, \mathrm{pH} 4.65,1: 20 \mathrm{w}: \mathrm{v}, 1 \mathrm{~h}$ shaking), with the exception that soil was weighed for the extractions and the results were calculated on a mass basis. All results reported in $\mathrm{mg} \mathrm{kg}^{-1}$ are calculated on an oven dry basis.

Easily soluble $\mathrm{P}$ was determined with water extraction (soil-to-solution ratio 1:10 w:v, shaken for $21 \mathrm{~h}$ at $21^{\circ} \mathrm{C}$, and filtered through a $0.2 \mu \mathrm{m}$ Nuclepore ${ }^{\circledR}$ polycarbonate filter). Total $\mathrm{P}$ concentration (A) of the extracts was measured using an ascorbic acid method after persulfate $\left(\mathrm{K}_{2} \mathrm{~S}_{2} \mathrm{O}_{8}\right)$ oxidation of the samples (APHA 1989). The filtrates were also analyzed for $\mathrm{P}$ using an ascorbic acid method without preliminary digestion (B). This $\mathrm{P}$ is normally considered to consist of $\mathrm{PO}_{4}-\mathrm{P}$, but unavoidably a small fraction of any hydrolyzable form of P present in the sample may be included (APHA 1989). Also mild acid hydrolysis of the water extracts (APHA 1989) was carried out prior to P analysis, but the results $(C)$ were identical to those obtained

Table 2. Phosphorus additions in the incubation experiment.

\begin{tabular}{|c|c|c|c|c|c|c|}
\hline \multirow[t]{2}{*}{$\mathrm{P}$ amendment } & \multirow{2}{*}{$\begin{array}{c}\text { Dosage } \\
\text { g pot }^{-1}\end{array}$} & \multirow{2}{*}{$\begin{array}{c}\mathrm{P} \text { content } \\
\mathrm{mg} \mathrm{g}^{-1}\end{array}$} & \multicolumn{2}{|c|}{$\mathrm{P}$ addition } & \multicolumn{2}{|c|}{$\mathrm{P}$ addition, $\mathrm{mg} \mathrm{kg}^{-1}$ soil } \\
\hline & & & $m g$ pot $^{-1}$ & $\mathrm{mg} \mathrm{dm}^{-3}$ & Organic soil & Mineral soil \\
\hline NPK-fertilizer & 0.5 & 32.24 & 16.1 & 35 & 53 & 32 \\
\hline Pig slurry & 12.5 & 1.74 & 21.7 & 47 & 71 & 43 \\
\hline
\end{tabular}


with no pretreatment (B). The unreactive $P$ present in the extracts was calculated as a difference $\mathrm{A}-\mathrm{B}$; it presumably consists of dissolved organic $\mathrm{P}$ not hydrolyzable in $\mathrm{PO}_{4}-\mathrm{P}$ analysis (because $\mathrm{C} \approx \mathrm{B}$ ). Due to the uncertainties of operational $\mathrm{P}$ fractionation of water extracts, the nomenclature suggested by Haygarth and Sharpley (2000) for the dissolved $\mathrm{P}$ species was adopted: $\mathrm{A}=$ total phosphorus, $\mathrm{TP}(0.2) ; \mathrm{B}=$ reactive phosphorus, $\mathrm{RP}(0.2)$; and the difference $(\mathrm{A}-\mathrm{B})=$ unreactive phosphorus, UP(0.2). The results were analyzed with twoway analysis of variance; pairwise comparisons were made with Tukey's test.

\section{Results}

The 12 freeze-thaw cycles during the 6-month incubation had no effects on any of the water extractable $\mathrm{P}$ fractions $(\mathrm{TP}(0.2), \mathrm{RP}(0.2), \mathrm{UP}(0.2))$ in the control or in the P-amended soils (Fig. 1). Freezing tended, however, to increase the concentration of $\mathrm{RP}(0.2)$ and its proportion of $\mathrm{TP}(0.2)$.
This tendency was most pronounced in the slurryamended soils, but in all cases it remained statistically insignificant because of the large variation in the results (Fig. 1).

Pig slurry amendment increased significantly water-extractable $\mathrm{TP}(0.2)(\mathrm{P}<0.05)$ in both soils but the effects of inorganic fertilizer did not reach a significant level. In all treatments, most of the water soluble P was molybdate-reactive: $87-99 \%$ in the organic soil and $84-92 \%$ in the mineral soil. Consequently, the fertilization-induced changes in $\mathrm{RP}(0.2)$ and in $\operatorname{TP}(0.2)$ were practically identical.

Both $\mathrm{P}$ amendments increased the results for $\mathrm{P}_{\mathrm{AAA}}$, whereas the freeze-thaw cycles had no significant effects on the P test result (Fig. 2). As suggested by Fig. 1 and Fig. 2, $\mathrm{P}_{\mathrm{AAA}}$ correlated strongly with both $\mathrm{TP}(0.2)$ and $\mathrm{RP}(0.2)$ on both soils $\left(\mathrm{R}^{2}\right.$ 0.82-0.93).

Organic $\mathrm{P}$ content $\left(\mathrm{P}_{\text {org }}\right)$ of the soils (Table 3) was not affected by $\mathrm{P}$ amendments or incubation conditions and did not correlate with any of the water soluble $\mathrm{P}$ fractions or $\mathrm{P}_{\mathrm{AAA}}\left(\mathrm{R}^{2}<0.04\right)$. On average, $\mathrm{P}_{\text {org }}$ accounted for $35 \%$ of TP in the organic soil and for $19 \%$ in the mineral soil.

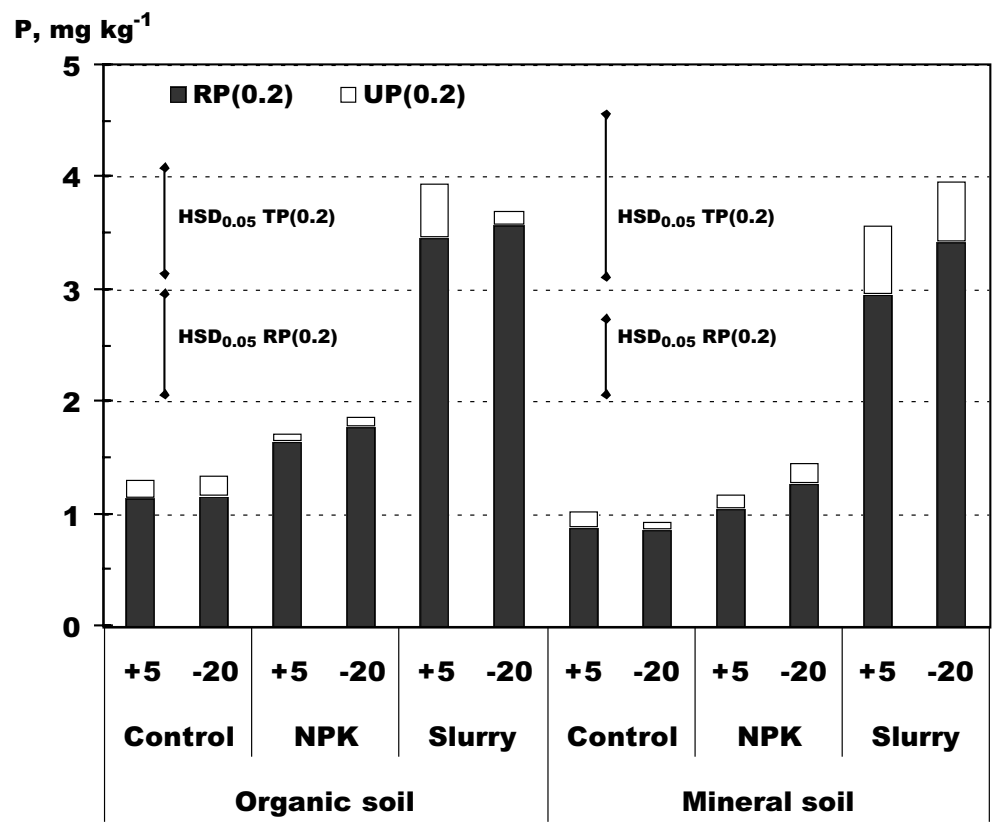

Fig. 1. Water-extractable total phosphorus $(\mathrm{TP}(0.2))$, and its composition of reactive phosphorus $(\mathrm{RP}(0.2))$ and unreactive phosphorus (UP(0.2)) in the soils after incubation. $\mathrm{HSD}_{0.05}$ is the significant difference at $5 \%$ risk according to Tukey's test. 
Vol. 14 (2005): 181-188.

Fig. 2. Acid ammonium acetateextractable phosphorus in the soils after incubation. $\mathrm{HSD}_{0.05}$ is the significant difference at $5 \%$ risk according to Tukey's test.

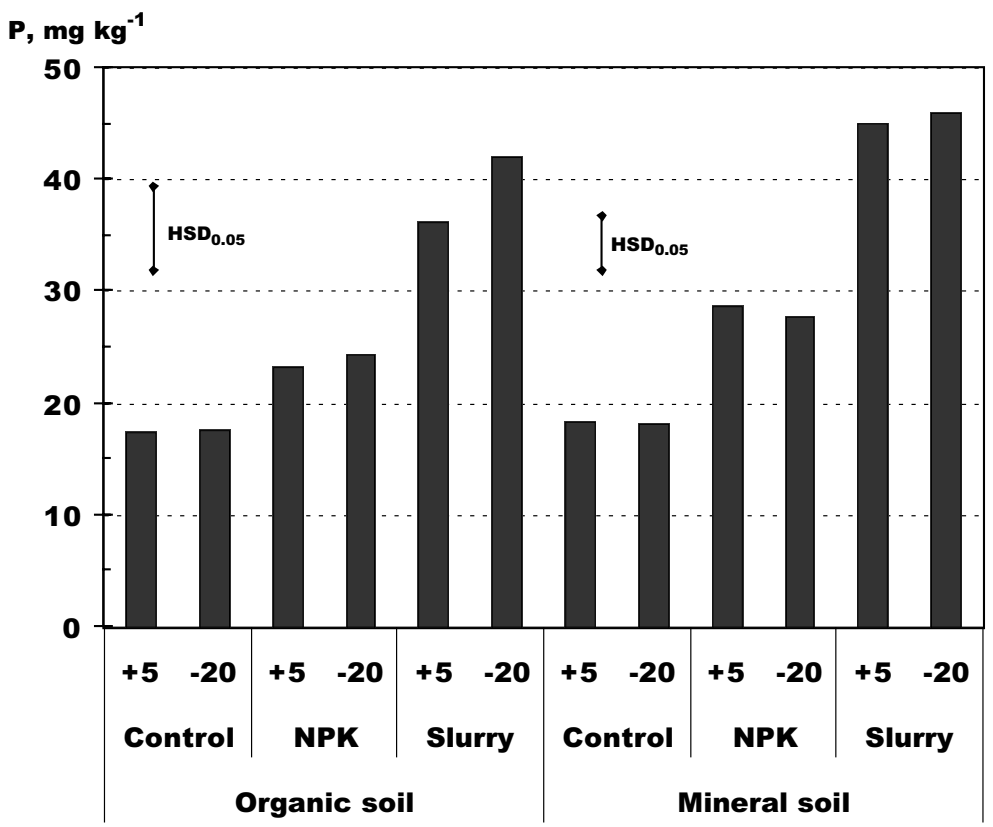

Table 3. $\mathrm{H}_{2} \mathrm{SO}_{4}$-extractable total soil phosphorus (TP) and organic phosphorus $\left(\mathrm{P}_{\text {org }}\right)$ in the soils after incubation.

\begin{tabular}{|c|c|c|c|c|c|}
\hline \multirow[b]{2}{*}{ Treatment } & & \multicolumn{2}{|c|}{ Organic soil } & \multicolumn{2}{|c|}{ Mineral soil } \\
\hline & & $\begin{array}{c}\mathrm{TP} \\
\mathrm{mg} \mathrm{kg}^{-1}\end{array}$ & $\begin{array}{c}\mathrm{P}_{\text {org }} \\
\mathrm{mg} \mathrm{kg}^{-1}\end{array}$ & $\begin{array}{c}\mathrm{TP} \\
\mathrm{mg} \mathrm{kg}^{-1}\end{array}$ & $\begin{array}{c}\mathrm{P}_{\text {org }} \\
\mathrm{mg} \mathrm{kg}^{-1}\end{array}$ \\
\hline \multirow[t]{2}{*}{ Control } & +5 & $1428^{a}$ & $542^{\mathrm{a}}$ & $632^{\mathrm{a}}$ & $106^{\mathrm{a}}$ \\
\hline & -20 & $1409^{a}$ & $527^{\mathrm{a}}$ & $641^{\mathrm{ab}}$ & $139^{\mathrm{a}}$ \\
\hline \multirow[t]{2}{*}{ NPK } & +5 & $1470^{\mathrm{ab}}$ & $514^{\mathrm{a}}$ & $651^{\mathrm{ab}}$ & $128^{\mathrm{a}}$ \\
\hline & -20 & $1475^{\mathrm{ab}}$ & $498^{\mathrm{a}}$ & $697^{\mathrm{ab}}$ & $161^{\mathrm{a}}$ \\
\hline \multirow[t]{2}{*}{ Slurry } & +5 & $1551^{\mathrm{b}}$ & $545^{\mathrm{a}}$ & $711^{\mathrm{ab}}$ & $123^{\mathrm{a}}$ \\
\hline & -20 & $1539^{b}$ & $516^{\mathrm{a}}$ & $730^{\mathrm{b}}$ & $128^{\mathrm{a}}$ \\
\hline
\end{tabular}

Figures denoted with the same superscript do not differ at 5\% risk according to Tukey's test.

Fertilization increased the total soil $\mathrm{P}$ content measured with ignition and $\mathrm{H}_{2} \mathrm{SO}_{4}$ extraction (TP), but this analysis was not able to distinguish between the P treatments (Table 3). The variation between the replicates was very large, which implies to an uneven distribution of added $\mathrm{P}$ in the experimental vessels. In the slurry treatment, recoveries for the TP analysis were suspiciously high: $179 \%$ and $194 \%$ for the two soils (Table 4). In the fertilizer treatment, the recoveries were close to the expected $100 \%$. Incubation temperature had no effect on recovered $\mathrm{P}$ (data not shown). The recovery of added $\mathrm{P}$ remained very low in the water extraction, but was markedly higher in the acid ammonium acetate extraction.

\section{Discussion}

The negligible effect of freeze-thaw cycles on the soil P test results was unexpected, because a number of previous incubation studies have shown that 
Soinne, H. \& Peltovuori, T. Effects of freezing on soil phosphorus

Table 4. Increase of phosphorus extracted in fertilized soils after incubation as a percentage of phosphorus added in the beginning of the experiment as mineral fertilizer (NPK) or as pig slurry.

\begin{tabular}{lccccc}
\hline Analysis & \multicolumn{2}{c}{ Organic soil } & & \multicolumn{2}{c}{ Mineral soil } \\
\cline { 2 - 3 } \cline { 5 - 6 } & NPK & Slurry & & NPK & Slurry \\
& $\%$ & $\%$ & & $\%$ & $\%$ \\
\hline $\operatorname{TP}(0.2)$ & 0.9 & 3.5 & & 0.9 & 6.3 \\
$\mathrm{RP}(0.2)$ & 1.1 & 3.4 & & 0.9 & 5.4 \\
$\mathrm{P}_{\text {AAA }}$ & 12 & 31 & & 31 & 63 \\
$\mathrm{TP}$ & 102 & 179 & & 116 & 194 \\
\hline
\end{tabular}

$\mathrm{TP}(0.2)=\mathrm{H}_{2} \mathrm{O}$-soluble total phosphorus, $\mathrm{RP}(0.2)=\mathrm{H}_{2} \mathrm{O}$-soluble reactive phosphorus, $\mathrm{P}_{\mathrm{AAA}}=$ acid ammonium acetate extractable phosphorus, $\mathrm{TP}=\mathrm{H}_{2} \mathrm{SO}_{4}$-extractable total soil phosphorus

freezing increases P extractability, especially in organic soils (Allen and Grimshaw 1962, Hinman 1970, Ron Vaz et al. 1994). A possible explanation for the insignificant effects of freezing in this experiment is the long incubation time that allowed effective sorption of $\mathrm{P}$, which led to small recoveries of water-extractable P (Table 4) and probably increased the variability of the results. In previous experiments the effects of freezing have usually been most distinctive after a few days or weeks of freezing. The effects of freezing have also been most distinctive in soils of low $\mathrm{P}$ status while the $\mathrm{P}$ status of our soils was moderate or high $\left(\mathrm{P}_{\mathrm{AAA}}\right.$ results $>17 \mathrm{mg} \mathrm{kg}^{-1}$ ). This may have masked the gentle effects of freezing. Due to the good P status of our soils, a very high proportion of water soluble $\mathrm{P}(>85 \%)$ was $\mathrm{RP}(0.2)$, leaving a minor role for organic components in soil $\mathrm{P}$ dynamics. Ron Vaz et al. (1994) found no freezing-induced changes in $\mathrm{P}_{\mathrm{AAA}}$ in a high $\mathrm{P}$ status mineral soil, but an increase in a low $\mathrm{P}$ status organic soil. Also Lockman and Molloy (1984) observed an increase of soil $\mathrm{P}$ test results during the winter months only in unfertilized test plots. Interestingly, Campbell et al. (1984) reported over-winter increases in soil $\mathrm{P}$ test results during the first 12 years of a long-term field experiment, but these responses 'disappeared' after running the experiment for another 12 years (Campbell and Zentner 1993). It is possible that the $\mathrm{P}$ status of the soils increased during the experiment, and finally masked the effects of freezing on soil $\mathrm{P}$.

Most of the UP(0.2) in the extracts was probably organic $\mathrm{P}$ because no increases in molybdate reactive $\mathrm{P}$ were detected after mild acid hydrolysis of the water extracts (solution C). According to Chardon et al. (1997), the organic $\mathrm{P}$ in pig slurry is mostly associated with high molecular weight compounds, and part of this $\mathrm{P}$ is hydrolyzed during molybdenum blue $\mathrm{P}$ analysis. Therefore, it is probable, that at least in the slurry treatments, most of the $\operatorname{UP}(0.2)$ and an unknown fraction of $\mathrm{RP}(0.2)$ of the water extracts (Fig. 1) was organic. Soluble organic $\mathrm{P}$ is an ecologically important fraction because it has higher mobility than $\mathrm{PO}_{4}-\mathrm{P}$ (Schoenau and Bettany 1990, Chardon et al. 1997) and therefore a potentially larger risk of leaching to surface waters.

The amount of $\mathrm{P}$ added to the soils $\left(70 \mathrm{~kg} \mathrm{ha}^{-1}\right.$ in the fertilizer and $94 \mathrm{~kg} \mathrm{ha}^{-1}$, of which $71 \mathrm{~kg} \mathrm{ha}^{-1}$ is accounted for as plant available, in the slurry) is roughly five times higher than customary P fertilization in small grain production in Finland. It is noteworthy, that despite heavy inorganic P fertilization, no significant effect on water soluble $\mathrm{P}$ was found after the six-month incubation period (Fig. 1). In $\mathrm{P}_{\mathrm{AAA}}$ analysis, the effect of NPK fertilization was significant but still less than the effect of slurry (Fig. 2). In addition to the higher total $\mathrm{P}$ addition, the higher concentrations of easily soluble $\mathrm{P}$ in slurry-amended soils are probably due to smaller sorption of $\mathrm{P}$ because of the slow release of $\mathrm{P}$ and competitive sorption of soluble organic anions with $\mathrm{PO}_{4}-\mathrm{P}$ on oxide surfaces (Sibanda and Young 1986). These results suggest that organic $P$ amendments are better sources of $\mathrm{P}$ than easily soluble NPK fertilizers for winter crops or grass crops that have a time gap between fertilizer application and $\mathrm{P}$ uptake. The high solubility of pig slurry $\mathrm{P}$ in this experiment also raises a question 
Vol. 14 (2005): 181-188.

about the rationale for considering only $75 \%$ of slurry P plant available.

The greater solubility of manure $\mathrm{P}$ compared to fertilizer $\mathrm{P}$ can also be seen in the apparent $\mathrm{P}$ recoveries in the water and ammonium acetate extractions after incubation (Table 4). The TP results obtained for slurry-amended soils are suspiciously high. The high recovery suggests higher true $\mathrm{P}$ concentration in slurry than reported in Table 2, but the result is not suspiciously low - the reference value for pig slurry $\mathrm{P}$ content used for manure application calculations in Finland is $1.3 \mathrm{mg} \mathrm{g}^{-1}$ (Viljavuuspalvelu 2000). The small sample size used in the manure $\mathrm{P}$ analysis and heterogeneity of the material may have produced a large variation in the result as can be seen in the high relative standard deviation. The suspiciously high recoveries of added $\mathrm{P}$ could also be explained by insufficient mixing of the $\mathrm{P}$ amendments with the soils before incubation - especially the small amount of pig slurry was difficult to mix thoroughly with the soil. However, even if the results were calculated to obtain exactly $100 \%$ recovery for TP (Table 4 ), the recoveries of water-extractable $\mathrm{P}$ and $\mathrm{P}_{\mathrm{AAA}}$ would still be higher for slurry than for NPK fertilizer.

According to the results of this laboratory incubation experiment, time of sampling (fall vs. spring) would have no significant effect on soil $\mathrm{P}$ test results. Field experiments focused on soil sampling and freezing have produced variable results. In the studies cited here, the $\mathrm{P}$ test results increased during the winter, but this finding has not been straightforward in all experiments. According to Read and Cameron (1979), Nyborg et al. (1992) and Campbell and Zentner (1993), over-winter differences in soil $\mathrm{P}$ test results can be significant but unpredictable. Therefore, no recommendations in favour of fall or spring sampling can be given. Because of the possible seasonal variation of the results, however, it is advisable to sample at the same time every year (Nyborg et al. 1992).

Acknowledgements. The Finnish Drainage Research Foundation and the Kone Foundation are gratefully acknowledged for financial support given to this research.

\section{References}

Allen, S.E. \& Grimshaw, H.M. 1962. Effect of low-temperature storage on the extractable nutrient ions in soils. Journal of the Science of Food and Agriculture 13: 525-529.

APHA 1989. Standard methods for the examination of water and wastewater. American Public Health Association, American Water Works Association, Water Pollution Control Federation. Washington, D.C. p. 4,167181.

Campbell, C.A., Read, D.W.L., Winkleman, G.E. \& McAndrew, D.W. 1984. First 12 years of a long-term crop rotation study in southwestern Saskatchewan - bicarbonate-P distribution in soil and $\mathrm{P}$ uptake by the plant. Canadian Journal of Soil Science 64: 125-137.

Campbell, C.A. \& Zentner, R.P. 1993. Overwinter changes in Olsen phosphorus in a 24-year crop rotation study in southwestern Saskatchewan. Canadian Journal of Soil Science 73: 123-128.

Chardon, W.J., Oenema, O., del Castilho, P., Vriesema, R., Japenga, J. \& Blaauw, D. 1997. Organic phosphorus in solutions and leachates from soils treated with animal slurries. Journal of Environmental Quality 26: 372378.

Edwards, A.C. \& Cresser, M.S. 1992. Freezing and its effects on chemical and biological properties of soil. Advances in Soil Science 18: 59-79.

Elonen, P. 1971. Particle-size analysis of soil. Acta Agriculturae Fenniae 122: 1-122.

Haygarth, P.M. \& Sharpley, A. 2000. Terminology for phosphorus transfer. Journal of Environmental Quality 29: 10-15.

Hinman, W.G. 1970. Effects of freezing and thawing on some chemical properties of three soils. Canadian Journal of Soil Science 50: 179-182.

Kivisaari, S. 1979. Effect of moisture and freezing on some physical properties of clay soils from plough layer. Journal of the Scientific Agricultural Society of Finland 51: 239-326.

Kuo, S. 1996. Phosphorus. In: Sparks D.L. (ed.) Methods of soil analysis. Part 3. Chemical methods. SSSA Book Series no. 5. Soil Science Society of America and American Society of Agronomy. Madison, Wisconsin, USA. p. 869-919.

Lockman, R.B. \& Molloy, M.G. 1984. Seasonal variations in soil test results. Communications in Soil Science and Plant Analysis 15: 741-757.

Miller, R.D. 1980. Freezing phenomena in soils. In: Hillel, D. (ed.). Applications of Soil Physics. Academic Press, New York. p. 254-299.

Niskanen, R. 1989. Extractable aluminium, iron and manganese in mineral soils I. Dependence of extractability on the $\mathrm{pH}$ of oxalate, pyrophosphate and EDTA extractants. Journal of Agricultural Science in Finland 61: 7378.

Nyborg, M., Malhi, S.S., Robertson, J.A. \& Zhang, M. 1992. Changes in extractable phosphorus in Alberta soils during the fall-winter-spring interlude. Communications in Soil Science and Plant Analysis 23: 337-343.

Peltovuori, T. \& Soinne, H. 2005. Phosphorus solubility and 
Soinne, H. \& Peltovuori, T. Effects of freezing on soil phosphorus

sorption in frozen, air-dried, and field-moist soil. European Journal of Soil Science (in press) doi: 10.1111/ j.1365-2389.2005.00726.x.

Read, D.L. \& Cameron, D.R. 1979. Changes in the amount of nitrogen and phosphorus in the soil between fall and spring sampling. Canadian Journal of Soil Science 59: 271-276.

Ron Vaz, M.D., Edwards, A.C., Shand, C.A. \& Cresser, M.S. 1994. Changes in the chemistry of soil solution and acetic-acid extractable $P$ following different types of freeze/thaw episodes. European Journal of Soil Science 45: 353-359.

Ryden, J.C. \& Syers, J.K. 1975. Rationalization of ionic strength and cation effects on phosphate sorption by soils. Journal of Soil Science 26: 395-406.

Schoenau, J.J. \& Bettany, J.R. 1987. Organic matter leaching as a component of carbon, nitrogen, phosphorus and sulfur cycles in a forest, grassland and gleyed soil. Soil Science Society of America Journal 51: 646-651.
Sibanda, H.M. \& Young, S.D. 1986. Competitive adsorption of humus acids and phosphate on goethite, gibbsite and two tropical soils. Journal of Soil Science 37: 197204.

Sillanpää, M. 1961. The dynamic nature of soil aggregation as affected by cycles of freezing and thawing. Acta $\mathrm{Ag}$ riculturae Scandinavica 11: 87-94.

Soil Survey Staff 1998. Keys to soil taxonomy. 8th ed. United States Department of Agriculture and Natural Resources Conservation Service. Washington D.C. 326 p.

Viljavuuspalvelu 2000. Viljavuustutkimuksen tulkinta peltoviljelyssä. Viljavuuspalvelu Oy. Mikkeli. 32 p.

Vuorinen, J. \& Mäkitie, O. 1955. The method of soil testing in use in Finland. Agrogeological Publications No 63. $44 \mathrm{p}$.

Wang, F.L. \& Bettany, J.R. 1993. Influence of freeze-thaw and flooding on the loss of soluble organic carbon and carbon dioxide from soil. Journal of Environmental Quality 22: 709-714.

\title{
SELOSTUS
}

\section{Maan jäätymisen vaikutus vesiliukoisen ja viljavuusanalyysissä uuttuvan fosforin määrään}

\author{
Helena Soinne ja Tommi Peltovuori \\ Helsingin yliopisto
}

Pohjoismaissa maat jäätyvät lähes säännöllisesti, mutta jäätymisen vaikutuksia maan kemiallisiin ominaisuuksiin on tutkittu melko vähän. Tässä työssä selvitettiin toistuvien jäätymis-sulamissyklien vaikutuksia fosforin (P) käyttäytymiseen multamaalla ja multavalla hiuemaalla. Maiden viljelyhistoria oli käytännössä identtinen ja P-tila hyvä. Tulosten perusteella pyrittiin arvioimaan $\mathrm{mm}$. maanäytteen ottoajankohdan vaikutusta viljavuusanalyysin P-lukuun ja maan jäätymisen vaikutusta syysviljojen fosforilannoituksen tehoon.

Maihin lisättiin sian lietelantaa tai NPK-lannoitetta (20-3-9), ja niitä muhitettiin tasaisessa $+5^{\circ} \mathrm{C}$ lämpötilassa tai kahden viikon jaksoissa $+5^{\circ} \mathrm{C} \mathrm{ja}-20^{\circ} \mathrm{C}$ lämpötiloissa yhteensä 24 viikkoa. Molemmissa käsittelyissä oli mukana myös kontrollikoejäsenet, joihin ei lisätty fosforia. Käsittelyjen jälkeen maista analysoitiin vesiliukoisen reaktiivisen ja ei-reaktiivisen fosforin pitoisuus sekä viljavuusfosfori.

Muhituksen jälkeen NPK-lannoitetta saaneiden maiden vesiuuttoisen reaktiivisen P:n pitoisuudet eivät poikenneet merkittävästi lannoittamattomista kontrollikoejäsenistä. Sian lietelantaa saaneissa maissa pitoisuudet olivat sen sijaan selvästi suurempia kuin kontrollissa, vaikka niissäkin suurin osa lisätystä P:sta oli pidättynyt maahan. Tuloksen perusteella lannan P on muhitusolosuhteissa pitempivaikutteista kuin NPK-lannoitteen P ja siksi sopivaa esim. syysviljojen lannoitukseen. Tulokseen vaikuttaa osaltaan myös se, että ohjeen mukaan lannan fosforista lasketaan kasveille käyttökelpoiseksi vain $75 \%$, ja siksi lannassa saa levittää enemmän fosforia kuin NPK-lannoitteessa.

Jäätymisellä ei ollut juurikaan vaikutusta maista muhituksen jälkeen tehtyjen fosforianalyysien tuloksiin, vaikka toistuva jäätyminen ja sulaminen hieman näyttikin kasvattavan vesiliukoisen reaktiivisen P:n pitoisuutta. Näytteenottoajankohdalla ei siten näyttäisi olevan vaikutusta maasta tehtävien $\mathrm{P}$-analyysien tuloksiin. Muualla tehdyissä tutkimuksissa talvella tapahtuvan jäätymisen on usein todettu kasvattavan tuloksia loppukesällä otettuihin näytteisiin verrattuna. Tässä kokeessa saatuihin tuloksiin vaikutti todennäköisesti pitkä muhitusaika, jonka kuluessa jäätymisen mahdollisesti vapauttama fosfori ehti pidättyä maahan, sekä koemaiden hyvä P-tila. Tällaisilla mailla jäätymisen vaikutukset ovat aiemmissakin tutkimuksissa olleet pieniä. 